Opposed to this theory are the following facts: (1) The natural mounds in many cases do not occur in situations favorable for camp sites. (2) They often occur in elevated locations, where there is absolutely no reason for artificial 'elevated sites for habitations.' Regarded as ruined habitations, or wigwam sites, it is very important to consider their vast number and the extent of territory covered. On this basis they would indicate, in many parts of Louisiana and Texas, an intensity and multiplicity of life not now duplicated in any rural community in the world. The sustenance of such vast communities would be entirely beyond the capabilities of the people who built the true Indian mounds. (4) The natural mounds generally occur on the poorest land in the northern Louisiana region, and this fact is strongly opposed to any supposed agricultural significance.

No one doubts that there are. numerous Indian mounds throughout this region, but the natural mounds belong to an entirely different class and should not be confused in this discussion with the artificial ones.

\section{A. C. VEATCH.}

\section{U. S. Geological Survey, \\ WASHINGTON, D. C., \\ December 2, 1905.}

\section{SPECIAL ARTICLES.}

T'HE TERMINOLOGY OF ABERRANT CHROMOSOMES AND THFIR BEHAVIOR IN CERTAIN HEMIPTERA. ${ }^{1}$

Comparative studies of the last few years have brought to light the occurrence of different kinds of chromosomes within the same cell, curiously modified or aberrant structures. These have been described in the spermatogenesis of various insects, as in the Orthoptera (by McClung, Wilcox, de Sinéty, Sutton, Baumgartner, Montgomery, Stevens), the Hemiptera (by Henking, Montgomery, Paulmier, Gross, Wilson), Odonota (McGill), and Coleoptera (Voinov, Stevens); in Chilopoda (by Blackman and Medes); and in Araneæ (by Wallace and Montgomery). I have shown that they are not present in the Protracheata (Peripatus). For these a considerable variety of names has been proposed, most of which

${ }^{1}$ Publications from the Zoological Laboratory of the University of Texas, No. 71 . are good appellatives, but all are inconvenient on account of their length or double form. There is a pressing need for a conciser and more uniform nomenclature, and the following terminology is here proposed to cover the three known kinds of chromosomes found to occur in the groups above mentioned.

Chromosome, a name introduced by Waldeyer, to be retained on account of its long usage as a convenient collective term, and also to be applied in those cases where all the chromosomes of a cell show essentially the same behavior. But when more than one kind occurs in a cell, they are to be distinguished as follows:

1. Autosoma (or autosome), the usual or non-aberrant chromosomes, called by me previously ordinary chromosomes.

2. Allosoma (or allosome), the modified chromosomes that behave differently from the preceding. This term is much more convenient than the appellative heterochromosome previously proposed and used by me, for the latter has an excessive length. Two kinds of allosomes are known in spermatogenesis and may be named respectively:

(a) Monosoma (or monosome), allosomes that are unpaired in the spermatogonia. These have been variously termed accessory chromosomes (McClung), chromosomes spéciaux (de Sinéty), chromosomes $x$ and unpaired ordinary chromosomes (Montgomery), and heterotropic chromosomes (Wilson).

(b) Diplosoma (or diplosome), allosomes that are paired in the spermatogonia. These correspond to what have been previously denominated chromatin nucleoli (Montgomery), Chromosome nucleoli (in parte), small chromosomes (Paulmier), and idiochromosomes (Wilson).

It is after considerable hesitation that I decided to propose these new names, for cellular nomenclature is already heavily overburdened, and I do so in the hope that they may be accepted in the spirit in which they are offered, namely, to attain greater brevity and convenience in writing. When one has to use words frequently he desires them as short as possible. And though I call upon fellow workers to discard their previous names, 
an attitude that would appear ungenerous and might even arouse some hostility, yet at the same time I relinquish previous names of my own that have been employed in various papers and have been adopted to some extent by others. Indeed, it would have been just as satisfactory to me had these emendations proceeded from some other worker.

In the second place a preliminary report upon reinvestigations of the spermatogenesis of two families of the Hemiptera heteroptera will be given in brief.

In the Pentatomidæ there is one pair of diplosomes in the spermatogonia, which always conjugate to form a bivalent one in the early growth period; these relations are exactly as I previously described them. Trichopepla only appears to possess an additional pair of very minute components. But I had formerly concluded that such a bivalent diplosome in this family always divides reductionailly in the first maturation mitosis, so that its two components would be carried to different daughter cells (second spermatocytes). Wilson has recently shown, however, that in this first mitosis the two diplosomes lie separately in the equatorial plate, and that each divides there equationally; and he finds that in each daughter cell (second spermatocyte) the two daughter diplosomes conjugate in the equatorial plate and are there separated by a reduction division. Wilson is quite correct with regard to this phenomenon, and I had failed to notice (except in Euschistus tristigmus) that in the later growth period of the first spermatocytes there takes place a separation of the components of the first bivalent diplosome. Further, I have recently found that in all the genera reexamined each diplosome becomes longitudinally split during the growth period. As to the number of autosomes in the spermatogonia of the Pentatomidæ: in Euschistus variolarius there are usually twelve, but in two cells there are at least thirteen, and possibly fourteen; the meaning of these differences I have not yet determined. There are also twelve autosomes' in Euschistus tristigmus, Nezara hilaris, Perillus confluens, Conus delius and Trichopepla semivittata. There are fourteen in Podisus spinosus and
Cosmopepla, carnifex; my preparations of Peribalus limbolaris have faded to such an extent that I was not able to restudy this form.

In the Coreidæ I had previously described the occurrence of monosomes only for Harmostes, Protenor, Alydus eurinus, and suggested the possibility of the presence of a monosome in Chariesterus. Wilson has recently shown that there is a monosome also in Anasa, contrary to the earlier descriptions of Paulmier and myself. Reexamination of my preparations demonstrates that in all the Coreidæ studied there occurs a monosome in the spermatogenesis. It is the odd chromosome of the spermatogonia, always divides in the mitoses of these cells, divides also in the first maturation division, but in the second maturation division passes undivided into one of the daughter cells (spermatids). In all the genera studied this mohosome retains its compact form during the growth period of the spermatocytes. Further, in each species studied of the Coreidæ there is a single pair of diplosomes in the spermatogonia, these regularly conjugate in the growth period, and divide reductionally in the first maturation division, as previously described by me. To these observations I can now add that each diplosome becomes. longitudinally split in the growth period, and that each divides equationally in the.second maturation division; and that they remain compact during the growth period in Anasa, Corizus, Harmostes, Protenor and Chariesterus, but not in Alydus and Metapodius. The number of chromosomes in the species investigated is as follows: Anasa tristis, A. armigera, A. sp. (from California), Metapodius terminalis: eighteen autosomes, one monosome, two diplosomes; in Alydus pilosulus, A. eurinus, Corizus alternatus, Harmostes reflexulus and Protenor belfragei: ten autosomes, one monosome, two diplosomes; no clear views of spermatogonic monasters of Chariesterus antennator were found, but judging from the relations in the spermatocytes there are in the spermatogonium probably: twenty-four autosomes, one monosome and two diplosomes.

The main errors in my preceding work 
arose from having neglected to study in certain species the phenomena of the second reduction mitosis.

The preceding observations apply only to the spermatogenesis. Wilson has recently shown that in Anasa tristis, Protenor belfragei and Alydus pilosulus there is one less chromosome in the spermatogonia than in the ovogonia, and from this most important observation has drawn interesting conclusions relating particularly to the determination of sex. Before the receipt of this last note by Wilson I had determined that this' is the case in Anasa sp. also.

These observations with further ones on other families will be detailed in a later publication. A point to which I would again draw attention is the value of chromosomal relations as a taxonomic character, discussed in a preceding paper, and within a few months reiterated by McClung. The number of the chromosomes is less constant than relations of behavior. All the Coreidæ have one monosome and a pair of diplosomes; the monosome divides in the first maturation division, probably equationally, but never in the second; the diplosomes conjugate in the growth period of the spermatocytes, remain united until they become separated by a reduction division in the first maturation mitosis, then each divides equationally in the second. The Pentatomidæ possess no monosomes; all have one pair of diplosomes (Trichopepla possibly two), which regularly conjugate in the early growth period, later separate, each divides equationally in the first maturation division, they conjugate again in the second spermatocyte and there this bivalent diplosome becomes reductionally divided. Thus one family has only diplosomes, the other these as well as a monosome; in the one the diplosomes divide first equationally, then reductionally, while in the other family the sequence of the divisions is just the reverse.

The conviction almost forces itself upon one that chromosomal relations not only furnish the basis for any understanding of the processes called heredity and differentiation, but also bid fair to become the basis of taxonomy. Thos. H. Montgomery, Jr. November 24, 1905.

\section{SCIENTIFIC NOTES AND NEWS.}

The American Association for the Advancement of Science and six affiliated societies are meeting in New Orleans as we go to press. We hope to publish next week the official report of the meeting. Reports of the societies meeting with the association at New Orleans and of those. meeting in Ann Arbor, New York and elsewhere will follow as soon as possible. Professor Dr. W. H. Welch, professor of pathology at the Johns Hopkins University, has been elected president of the association.

Professor William James, of Harvard University, has been elected president of the American Philosophical Association.

Professor James R. Angell, of the University of Chicago, has been elected president of the American Psychological Association.

M. Henri Moissan, professor of chemistry at Paris, has been elected a foreign member in the Munich Academy of Sciences, and Dr. Warburg, the president of the Reichsanstalt, and Dr. Karl Chunn, professor of zoology at Leipzig, have been elected corresponding members.

Mr. Отто Veach has been appointed state geologist of Georgia.

Dr. MAx UHLe, who for the past seven years has been engaged in archeological research in Peru as the head of the Hearst Expedition for the University of California, has concluded the field work of the Hearst Expedition and has accepted the position of director of the National Archeological Museum of Peru. In a letter received from Dr. Max Uhle he states that the government of Peru will prohibit the exploration of archeological sites by foreigners, unless under the direction of the government, and will also prohibit all exportation of archeological objects after January 1, 1906.

We learn from The Botanical Gazette that Dr. J. C. Arthur, of Purdue University, is preparing the manuscript on the plant rusts of North America for the "North American 